Roy Kemmers, Stef Aupers, Dick Houtman, Jeroen van der Waal (2014) 'State of Disgrace: Popular Political Discontents about the Dutch State in the 2000s,' forthcoming in Parliamentary Affairs; Advance Access, doi: 10.1093/pa/gst036

http://pa.oxfordjournals.org/cgi/content/abstract/gst036?ijkey=y1Tzp3BSWdIK406\&keytype $=$ ref

\title{
Summary
}

While it is widely acknowledged that politics and politicians have fallen from grace among large parts of the public in western democracies, it is less clear what the latter's political discontents are about. To find out, we performed an interpretative content analysis of the letters to the editor of the largest popular Dutch newspaper in the 2000s (2000-2009). It yielded three empirically grounded discourses of political discontents about 'the state' -shorthand for the government, its agencies, officials, judges, politicians and political parties- : 'the incompetent state', 'the alienated state', and 'the corrupted state'. The relevance of these findings is subsequently discussed in the light of research on political distrust and contemporary populism.

Keywords: cultural sociology; interpretative content analysis; political discontent; political distrust; populism 


\title{
State of Disgrace
}

\section{Popular Political Discontents about the Dutch State in the 2000s}

Roy Kemmers*, Stef Aupers*, Dick Houtmanª Jeroen van der Waal*

\begin{abstract}
All (*) authors are affiliated with the Centre for Rotterdam Cultural Sociology (CROCUS), Department of Sociology, Erasmus University Rotterdam, the Netherlands.

${ }^{a}$ Center for Sociological Research, University of Leuven, Belgium.
\end{abstract}

Over the last decades, governments and politicians have steadily fallen from grace in western societies (Dalton, 2005; Pharr and Putnam, 2000; Hibbing and Theiss-Morse, 1995). Although this has by now become a sociological mainstay (see however: Van de Walle et al., 2008), it remains by and large unclear what political discontents among the public are actually about (cf. Hay and Stoker, 2009; Kaina, 2008; Van Wessel 2010). In most of the literature political discontent is referred to in general and abstract terms - as 'low levels of trust in politicians' without specifying the exact nature of such discontents or disentangling the exact ways they are formulated by the people themselves. In fact, van Wessel (2010: 505) observes, 'little is known of how citizens' own perspectives on what happens between them and political actors, institutions and processes might contribute to our understanding of disaffection'. Given this 'big unknown in how [citizens] come to understand politics' (Hay and Stoker, 2009: 233) we aim to investigate political discontents as these are formulated and voiced by the people themselves. Before doing so, we will first critically discuss two prominent lines of research into political 
discontents that, despite their respective merits, do not allow such an endeavour, either because of an exclusive focus on the political-institutional domain, or because of a reliance on survey questions.

The first of these focuses on the role that political discontents play for the rising salience of populist parties (e.g., Canovan, 1999, 2005; Taggart, 2000; Mudde, 2004, 2010; Mény and Surel, 2002). Populism, a dominant definition holds, is 'an ideology that considers society to be ultimately separated into two homogeneous and antagonistic groups, "the pure people” versus "the corrupt elite", and which argues that politics should be an expression of the [general will] of the people' (Mudde, 2004: 543). This is exactly what populist parties all over Europe emphasise, and it does therefore not surprise that discontents about established parties and politicians among the public underlie their support. Studies on the salience of political discontents for populism, however, mostly analyse electoral results, party programs and statements by populist leaders (Pauwels, 2011), and are exclusively focused on their formulation in the political-institutional sphere (see however: Uitermark et al., 2012; Rooduijn, 2013 for some exceptions). Scholars studying populism acknowledge that political discontents can exist in times of low political articulation, but their interest predominantly lies in their expression in the political-institutional sphere. Taggart (2000: 5), for instance, has taken this position, stating that although '[c]ulturally, populism runs through societies as the celebration of the virtue of ordinary people (..)', he is mainly interested in 'populism once it is a political phenomenon, when it is mobilized'. Such a focus on the political-institutional sphere did yield many valuable insights into the relevance of political discontents for the populist ideology and their articulation by populist leaders, but is, by definition, less informative on how political discontents are formulated and expressed by ordinary citizens. 
The second line of research on political discontents focuses on the declining levels of public trust in government, politicians and institutions (e.g., Dalton, 2005; Norris, 1999; 2011; Pharr and Putnam, 2000; Hibbing and Theiss-Morse, 1995; Stoker, 2006; Hay, 2007; Van Wessel, 2010; Korsten and de Goede, 2006; Kaina, 2008; see however: Bovens and Wille, 2011; Van de Walle et al., 2008). In reports of those declines, scholars generally express concerns about the level of public support for either specific (democratic) institutions or for democratic principles at large, and, based on that, often formulate concrete remedies to solve this 'political disenchantment' (Stoker, 2006). In many cases, these boil down to expanding citizen participation, the provision of more information, transparency, and institutional reform (Norris, 2011: 238).

Contrary to studies of populism, those focusing on trust in the government, politicians and institutions do address political discontents that are not articulated in the politicalinstitutional sphere. Yet, these studies strongly rely on survey data. As a result, political discontents are measured by means of closed questions that have been formulated by statistical bureaus and the researchers themselves. This can be considered problematic since

'in empirical research in particular, citizens' views are studied through the analysis of factors in causal relations; rarely are citizens approached as actors having their own understandings of politics. This suggests that important explanations of political disaffection may be ignored' (Van Wessel, 2010: 505).

In addition, such survey questions on political discontents measure the level or degree of distrust vis-à-vis politicians, politics and the government (e.g., Halman, 2006; Dekker et al., 2006; Norris, 2011). This means that political discontent is measured by questions on whether one 'tend[s] to trust or tend[s] not to trust' different institutions (Eurobarometer series), 'how much confidence' one has in certain institutions, or by asking one's opinion on 'how democratic 
the country is governed today' on a scale from 1 to 10 (World Values Survey, in Norris, 2011).

Such survey data can be of great value for assessing trends in political distrust but can, however, not provide insight in the different complaints citizens formulate themselves or the specific reasons they give for their discontents. Such insight, we hold, provides the opportunity to better understand contemporary distrust in the government, politicians and institutions, as well as the cultural breeding ground for populism (cf. Kaina, 2008; Van Wessel 2010).

In what follows we will, therefore, study contemporary political discontents as these are formulated by the people themselves. To do so, we conduct an inductive study that enables us to answer the research question: what are contemporary political discontents actually about?

\section{Case, method and data}

In this case study we will focus on popular discontents in the Netherlands in the 2000s (20002009). The Netherlands has experienced a sudden drop in popular trust in politics between 2002 and 2006. And this 'Dutch drop' (Bovens \& Wille, 2008; Hendriks, 2009), has only tentatively been explained by the prevailing 'objective' factors and the study of political distrust has therefore been said to require a focus on 'citizens' perceptions of the political system' (Van der Meer, 2010: 532).

In addition, for the Netherlands, as for many West European countries, this decade has been characterised by political turmoil, especially since the rise of the late Pim Fortuyn in 2001, who put the issues of immigration and integration on the political agenda with a firm antiestablishment rhetoric (Houtman et al., 2012), and the subsequent growing popularity of rightwing populist parties such as Geert Wilders' PVV. ${ }^{1}$ Both Pim Fortuyn and Geert Wilders

\footnotetext{
${ }^{1}$ Pim Fortuyn, a former professor in sociology, shook up the Dutch political landscape by criticising established political parties - most notably the social democratic party (PvdA). He founded the Lijst Pim Fortuyn (LPF), which
} 
claimed that they voice the political discontents of ordinary people, suggesting that these had been neglected by established politicians and political parties. This most visible current manifestation of political discontents in the Netherlands therefore seems to have a specific newrightist character and has been conceptualised as ‘the silent counter-revolution'(Ignazi, 1992) or 'counterculture 2.0' (Houtman, 2011), with reference to the new-leftist anti-establishment ethic of the 1960s that has become known as the 'silent revolution' (Inglehart, 1977) or the ‘counterculture’ (Roszak, 1969).

To study the political discontents voiced by the people themselves we chose to analyse the letters sent to the editor of a newspaper. This choice is informed by the assumption that the letters to the editor section has

'historically (...) been seen by both journalism scholars and practitioners as a central public forum; a place where democracy blossoms because regular citizens are allowed a voice of their own. (..) [T] he normative vision informing the section is one of a public sphere institution that thrives through vigorous discussion and participation.' (WahlJorgenson, 2004: 90).

Although ordinary citizens may also express themselves online, on forums or in comment sections, these platforms, Wahl-Jorgenson argues, 'tend towards more specialized topics, the letters section is only restricted insofar as it takes the form of a response to items already placed on the news agenda by the paper (..). As such, it may deal with any topic of common concern or in the "public interest"' (2004: 92). ${ }^{2}$ For the purpose of the present study, the letters to the editor section is thus seen as a platform that allows ordinary citizens to share their political discontents.

gained substantial electoral support in the parliamentary elections of 2002, nine days after Fortuyn himself was assassinated. Geert Wilders, after being a Member of Parliament for the Liberals (VVD) until 2004, founded the Party for Freedom (PVV), which gained substantial electoral support in the parliamentary elections in 2006 and 2010 and currently holds $10 \%$ of the seats in Dutch Parliament. The PVV is a right-wing populist party, most notably known for their fierce critiques on the Islam.

${ }^{2}$ While unequal access to internet facilities was a solid argument in favor of letters sections over internet forums or message boards in the beginning of the decade under study, rising levels of internet use (e.g., CBS Statline, 2009) 
Although there is a wide variety of Dutch newspapers with a letters to the editor section available, we strategically selected the one most fit for the research at hand. That is, a newspaper that is widely considered to have a 'radar for the sentiments among the public at large' (Wolf, 2009: 482; authors' translation): De Telegraaf. This is by far the largest popular newspaper in the Netherlands and its letters to the editor section 'enables it to closely follow the daily discontents, worries and joys of (the most outspoken part of) her readers. As soon as politics in The Hague are debated, discontents reign', Wolf (idem) concludes in her study on the history of this newspaper. ${ }^{3}$ And indeed: recent research has confirmed that political discontents are especially salient among the readers of De Telegraaf (Dekker and den Ridder, 2011). All in all, a qualitative content analysis of the letters to the editor section of De Telegraaf is a strategic case for assessing contemporary political discontents in the Netherlands.

The letters to the editor of all De Telegraaf issues are freely accessible in the newspaper archive of the Dutch Royal Library in The Hague. The data are stored on microfilm and were copied by taking photos of the microfilm reader screen. Considering the vast number of letters to the editor published in the decade under study we needed to make a selection before our analysis. We took a representative random sample from the letters to the editor sections by means of the constructed week sampling method (Riffe et al., 1993; cf. Janssen et al., 2008). We followed Riffe et al. (1993), who concluded that two constructed weeks provide a representative sample of a year's newspaper editions and constructed two weeks of letters sections of De Telegraaf from a randomly selected Monday issue, a Tuesday issue, a Wednesday issue, etc., for each year under study. Such a random week has the advantage of controlling for day and periodical effects, i.e., it

have rapidly reduced this digital divide. With regards to (un)equal access, this has made the paper/digital consideration an increasingly arbitrary one.

${ }^{3}$ The Hague is the governing capital of the Netherlands and the city's name is therefore often used as shorthand for 'politics' or 'the political system'. 
limits the possibility that letters within a sample are biased towards certain salient events within a period or on particular days of the week. This method yielded a total sample of 1186 letters. $^{4}$

\section{The state under siege: an interpretative content analysis of letters to the editor}

We performed an interpretative content analysis, a method that strives for developing theory through the categorisation of content (Hijmans, 1996; cf. Glaser and Strauss, 1967). The first stage in the analysis consisted of identifying and selecting the letters that express political discontents in the broadest sense of the word, i.e. to make sure that no political discontents were excluded from the analysis. The bulk of the letters in our samples consisted of additions, appraisals, corrections and opinions in reaction to published articles or news-items, addressing rising prices, the quality of wines, rescue workers, child care, and many, many more issues not relevant here. A substantial number of letters that expressed political discontents in all its variety remained: these were letters expressing concerns, frustrations or dissatisfactions about the government, its agencies and officials, politicians and political parties (shorthand: the state). ${ }^{5}$ The interpretative content analysis that yielded the insights outlined below is based on this selection, which includes a total number of 120 letters to the editor of De Telegraaf from the years 2000-2009 - approximately 10\% of the letters selected by means of the constructed week method.

The analysis of these letters to the editor was based on the procedure of 'grounded theory’ (Charmaz, 2006; Glaser and Strauss, 1967): it consisted of an inductive process of coding

4 The sample of letters sections thus consists of two constructed weeks - that is 12 days (Monday through Saturday) - per year for each year in the decade under study, thus counting up to a total of 120 letters to the editor sections (((6 $* 2) * 10)=120$ ). The total number of letters was 1186 , which indicates that the mean number of letters per day was 10.

5 'The state': though the use of the term 'state' is often limited to the executive state apparatus, when referring to the subject matter of the letters to the editor of De Telegraaf in this study, it is used as a shorthand for a wider range of public actors, including legislative and judicial ones: the government, its agencies, officials, judges, politicians and political parties. 'The state' is thus shorthand for this collection of 'public actors'. 
and recoding, which resulted in a typology of three discourses of political discontents. These three discourses are conceptualised as 'the incompetent state', 'the alienated state' and 'the corrupted state', and represent the types of allegations found in the empirical analysis of the letters. In presenting the analysis these types are subdivided by the level of aggregation of the addressee under siege. This sub-typology distinguishes between 'people' (when a single official is scrutinised); 'groups or organisations' (when groups of officials or specific state agencies are under fire); and 'system' when the charges are aimed at the government, political- or other institutions that fall within the wide definition of the state (cf. Norris, 2011).

\section{The incompetent state}

This first discourse revealed by our analysis mostly consists of expressions of discontents about specific incidents or events with regard to the functioning of the state. The basic argument here is that the state has allegedly failed the tasks it is supposed to fulfil. Typical for this particular discourse is the aim to correct the state: authors that utilised it point out a particular problem allegedly caused by a politician or (political) organisation and often propose solutions or alternatives in calling for a change of policy or for replacing a particular official.

Starting with the lowest level of aggregation, one rather innocent example of citizens correcting an official comprises of someone asking for subtitles whenever (then) prime minister Balkenende talks: '[h]ow can the opposition even make anything out of his babbling? The prime minister is in dire need of speech therapy. At his own expense' (19-09-09). ${ }^{6}$ The most obvious examples consist of allegations of particular officials having failed. When in 2005 a convict that was involuntary committed escaped and killed a man, this prompted many people to express their discontents with the Secretary of Justice in letters to the editor of De Telegraaf. Whereas

\footnotetext{
${ }^{6}$ The references to letters refer to the date of publication in De Telegraaf (dd-mm-yy).
} 
one of those asked 'how long will this minister continue to mess things up and when will he see for himself that the Netherlands are through with him?', another claimed that 'the escaped convict can’t be blamed for this. He is sick. This murder is signed by [Minister of Justice] Piet Hein Donner' (both 17-06-05). Another official under fire was the mayor of Rotterdam, when it was revealed that he rewarded citizens of Moroccan descent financially for talking to him about their problems: 'the problems are well known; Aboutaleb should spend his time on solutions. (...) Job Cohen only drank cups of tea [meaning: merely talked, instead of firmly dealt, with those that according to critics caused problems; authors]. His 'apprentice" ${ }^{7}$ now appears to be putting it to the extreme' (20-10-09). These are, in short, illustrations of individual officials being criticised for their alleged incompetence, sometimes accompanied by suggestions on how to properly address the issue at hand.

Other frustrations focus on the functioning of state agencies or categories of officials. One of the besieged agencies in the letters to De Telegraaf is the police and the district attorney for traffic. In particular, their persistence in persecuting speeding drivers is contrasted with their alleged inability to catch 'real criminals': 'Victims who retaliate go to jail longer than the offenders; shop theft, violence, burglary and vandalism are hardly punished, while the citizen that is going to work is spied on like a potential crook by [DA] Mr. Spee and his pals' (03-0902). In sum, this argument goes, 'If the police and the justice department would show as much creativity, commitment and perseverance in fighting crime as they do in cashing tickets, we would now have a crime-free country' (01-02-2000). 'Politicians' as a group form another selfevident target that spark popular discontents. For example, in 2003 a reader is frustrated by the proliferation of the term 'volatile voters' and asks 'is the contemporary voter really so

\footnotetext{
${ }^{7}$ Mayor of Rotterdam Ahmed Aboutaleb previously was a Municipal counselor in Amsterdam during the reign of Mayor Cohen.
} 
unpredictable? I don't think so. I think the volatile voter is a frustrated or a cheated voter, (...) the real problem is the fact that politicians have forgotten to listen to their constituencies' (16-0103), suggesting that 'politicians' have neglected their core tasks. And after the murder of Pim Fortuyn, a reader comments that the Netherlands has made a fool of itself because something like that could happen 'under our rule of law': 'Ladies and gentlemen politicians, let this be another clear signal that something has to change in the Netherlands and that the times of tolerance and permissiveness are now really over' (10-05-02).

Besides being directed at individual or categories of officials and public agencies, the allegations of incompetence are also aimed at the highest level of aggregation: the government, or the 'whole system' is regularly discredited for what they do or neglect. This is illustrated in a letter published in 2002, when Dutch public debate fired up over the question whether two prisoners could be put into one cell, in which this discussion is contrasted with the situation in nursing homes for the elderly: 'six heavily demented elderly people in one room with only a nightstand for their personal belongings. No TV, no privacy. "The Hague” is apparently less worried about that. Wake up The Hague and cram our prisons' (17-01-02). And when it is announced that Mohammed B.'s internet use will be controlled, ${ }^{8}$ a reader reacts in a similar vein: ‘Have we gone completely mad? There are still families that can’t afford having internet. And a maniac killer will get his own computer and internet connection, paid for by the tax payer' (1907-05). Discussing the possibility of the populist PVV of Geert Wilders taking part in the next coalition, another reader argues that it's the established parties' own fault that this party attracts that many voters: 'They hesitate to take important decisions, postpone them or leave them to costly commissions (..) The PVV is not a threat to the established parties, they themselves are' (20-04-09).

8 'Mohammed B.' assassinated filmmaker and Islam-critic Theo van Gogh in 2004. 
While this first discourse clearly expresses criticism and frustrations about the state and public servants, it should be noted that the authors who employ it seem not to have lost all hope for improvement. The state is not so much totally rejected but corrected at particular points: politicians are held accountable for their mistakes and ought to suffer the consequences; particular policies are critiqued for being inefficient and should be revised; and when 'the system' itself is disputed it revolves around its prioritising. This type of discontents we conceptualised as ‘the incompetent state’ converges with Pippa Norris’ (1999; 2011) notion of the 'critical citizens'. From the 1960s and 1970s onwards, she argues, rising educational levels have inspired rising aspirations among many western citizens. In combination with bad government performance and negative news in the media, this has led to increased assertiveness among citizens. The discourse thus also converges with an orientation that Tarrow (2000: 289) referred to as 'vigilant skepticism'; he suggests that this critical attitude represents 'a less comfortable, but more robust democracy’.

\section{The alienated state}

The second type of discontents uncovered in the letters to the editor of De Telegraaf is dubbed 'the alienated state'. This type consists of accusations of agencies, officials and their policies as impersonal, overly bureaucratic and being alienated from the reality of everyday life. It resembles the Kafkaesque notion of bureaucracy as a complex system that seems out of human control. This discourse can ideal-typically be distinguished from that of 'the incompetent state': it entails a more profound and generalised discontent about the state, instead of case-specific corrections. 
Authors that utilise the discourse of the alienated state use various cases to illustrate their view that the state has particularly lost contact with the reality of 'ordinary people'. In 2000, when a Secretary of State worries about a rapport on welfare fraud, a reader labels it as naïve and claims that '[i]t is commonly known that the outcomes of this kind of research have to be multiplied by 3 to approximate the actual percentages' (17-11-2000). Individual officials are thus accused of not knowing what is happening 'in the real world', and of being completely unaware of what is crystal clear to the average citizen. In a comparable case, a reader rhetorically poses the question '[h]ow many times will our policy makers be shocked or surprised again about wrongdoings that ordinary citizens have known about for a long time?' (17-01-02).

Similar accusations are directed at state agencies and officials in general. One reader, when advocating the right for divorced fathers to visit their children, for instance, claims that 'our representatives symbolise their attitudes by talking with their hands in their pockets. They don't have a clue what's going on in society' (01-02-2000). And in 2005, a woman whose purse is stolen from her car, puts her car in reverse and drives into the thief, who tries to get away on a scooter. The thief dies, and the woman subsequently gets prosecuted. A reader is outrageous and reacts: 'Scum has to understand that from now on, they are running risks as well. Too bad for them, good for society,' and qualifies the prosecution as '[t]he umpteenth foul-up of the Public Prosecution Service, which is clearly out of touch with society' (22-01-05). Cases that supposedly testify to the state's alienation from everyday life appear quite frequently in the letters to the editor. When the Christian Democratic Party deploys a hot air balloon for their campaign in 2009 a reader 'understand[s] the message directly: 'one can rise to great heights on hot air. Especially when all the weight is thrown out” (20-05-09). And when the Secretary of Traffic announces an experiment to reward law abiding drivers, one letter writer concludes that 
'this proves that the regulators have totally lost control', while another hypothesises 'I think the plan (..) has been devised by officials who have been struck by the heat' (both 13-08-04).

The highest level of aggregation - the whole system (and the rules and regulations it produces) - is also qualified as out of touch with reality. This impersonal and reified sense of 'system' is aptly expressed in a letter stating that '[w]hat Pim Fortuyn has prioritised is a growing sense of discontent among a large part of the population about what I would like to typify as "collective irresponsibility". After all, no one is responsible anymore for decisions that are made "in the general interest"' (10-05-02). Several letters addressing the alienation of the state focus on legislation that is not effective, or even represents an obstacle to life in general and business life in particular. In 2006 a reader points out that an entrepreneur 'has to slash himself through an impermeable plethora of rules even before starting a business, let alone to keep it running' (20-09-06). Furthermore, when 'given the economic situation' curved cucumbers are re-allowed by the EU, a reader cynically comments: 'fortunately, when the economy recovers the cucumbers will again be supplied (...) in their "correct” shape, [after which] the praiseworthy bureaucracy can also be re-established' (15-11-08). Arguing that 'businesses are bullied away with an overabundance of bureaucratic regulations, overcrowded roads, exorbitant taxes and high wages' (19-04-03), one reader demonstrates that in De Telegraaf small business owners often comprise the main reference category of plain common sense, and that frustration of this category is therefore considered especially blameworthy. In sum, the system's rules and regulations, it is maintained in this discourse, lack any sense and, consequently, merely serve to keep a system running that is out of touch with reality.

The procedural formalism that is frequently being mocked in the letters to the editor of De Telegraaf, is furthermore experienced as dehumanising for individuals. This can be illustrated 
by a reader who expressed frustration over the case of Theo van Gogh's son, who was charged after skipping school on the day his father was murdered. The reader states this 'is yet another bureaucratic mistake of the ever expanding incompetent officialdom' (28-03-08). The proliferation of 'meaningless' or 'senseless' rules makes one reader even wonder whether 'that superior common sense that made us great has collapsed under suffocating regulations and alarming incompetence?' (02-08-2000).

Summarising, the basic argument of the second discourse found in our data - the alienated state - thus holds that the bureaucratic system of governance and its officials are out of touch with reality, their policies and rules are ‘inhuman’ and their actions consequently devoid of meaning. This is in line with Max Weber's suggestion that the formal rationalism, so prominent in modern bureaucratic institutions, collides with the substantive rationalism of individuals' beliefs and values (cf. Brubaker, 1982). Rationalisation in (state) bureaucracies - created as instruments of the collective will - may (or may not) be effective, but simultaneously motivates feelings of meaninglessness and alienation (Berger et al., 1974 [1973]). This is reflected in the discourse of the alienated state that was found in the letters to the editor of De Telegraaf.

\section{The corrupted state}

Whereas the previous section distinguished a discourse that fleshes out the state as $a$-moral - as a political system that has replaced moral meaning with formal rules and procedures - we now turn to discourse that portrays the state as immoral. We dubbed this category 'the corrupted state'. The general claim here is that political actors and institutions do not serve the general interest, as they should, but instead manipulate and abuse their power for personal, collective or ideological interests. In other words: whereas the previous discourse attributed the state's 
malfunctioning to its alienation from everyday reality, the discourse discerned here ascribes it to the ill will of politicians, officials, agencies or even the entire system.

One way in which vested interests are allegedly served is through officials abusing their power. A reader, for instance, calls the district attorney 'the impersonation of the bureaucratic elite that resists parliamentary decisions it doesn't like' (29-02-04). And in 2009 Minister of Finance Wouter Bos is discredited by a reader because he ' flexibly' deals with the information and advice provided to him by respected agencies as the CPB' ${ }^{9}$ Whereas Bos initially embraced the evidence that supported his policies, he later on rejected the figures when this proved to be more convenient. The reader appears to see this as the manipulation of facts and sarcastically comments: 'hats off for Minister Bos, who excellently navigates between the pitfalls of information and advice' (16-06-09).

Besides the ill will ascribed to individual officials, the letters that demonstrate the discourse of the corrupted state also frequently attribute bad intentions to groups of officials - for instance by referring to the salaries of parliamentary representatives. In particular, the 'waiting fees' received by former representatives are frequently contrasted with the liberalisation of the labour legislation relating to the dismissal of employees: ${ }^{10}$ 'How does our government intend to diminish the rights upon discharge while it is receiving waiting fees itself for another eight years?' asks one letter writer. Another one stresses that since more than half of the former members of parliament receives these waiting fees, 'this means that former representatives are either incompetent or scroungers (..)'(29-08-07). But the allegations directed at state officials pertain to more than their financial rewards. One reader, for example, questions the function of city districts in Amsterdam, by qualifying these as superfluous administrative layers that merely

\footnotetext{
${ }^{9}$ CPB: The Netherlands Bureau for Economic Policy Analysis.

${ }^{10}$ Former Members of Parliament maintain their salaries for a certain period. This provision is intended to compensate for the loss of income until finding new employment.
} 
serve the interests of those employed there: ‘a job circuit for politicians who don’t feel like actually working. Now they're sitting there making up rules 32 hours a week (...). Get rid of those districts' (02-01-08). Such group interests are also considered to underlie culpable passivity. For instance, when banks announce to apply stricter rules for their debtors after the 2008 banking crisis, a reader comments that 'an actually dedicated Secretary would prevent this, but of course this doesn't apply to the current group of Secretaries (..) they wouldn't want to jeopardise their next job as a manager at a bank.' (20-04-09).

Finally, corruption is also believed to have penetrated the highest levels: 'the establishment', this argument goes, maintains its position by influencing court decisions, allocating powerful positions among friends, and abusing its power in other ways. For instance, by smothering innovative ideas that might threaten the status quo. Such an allegation is, for instance, expressed by a reader who argues that established political parties have co-opted Pim Fortuyn’s ideas: ‘With popular (..) talk the people are distracted from our country’s real issues. Meanwhile, the power is allocated in a way that suits these [established] parties best. In the end, nothing will have changed. After a change of seats among the elite, purple has merely changed colour' (16-01-03). ${ }^{11}$ Another reader makes comparable allegations right after the murder of Fortuyn, explicitly capitalising 'they' and 'us', making it less specific than the one of the previous example, but more explicit in constructing an image of society consisting of two antagonistic groups: 'They have silenced him. They, who could not reply to his sharp rhetoric, his analyses and his interpretation of the voice of the people. Us, who should be able to express our wishes in a constitutional democracy. Us, who have been held aloof for too long (...). But Us

\footnotetext{
11 'Purple' represents the political color of the governing coalition between 1994 and 2002, mocked by Pim Fortuyn in his famous 2002 book De puinhopen van acht jaar paars ['The debris of eight years of purple rule', our translation].
} 
know who is to blame...' (10-05-02). ${ }^{12}$ In a similar vein, the advancement of the European Union is seen as undemocratic project of a self-serving elite: ‘Turkey will probably also be shoved down our throats, just like the euro and open borders' (14-10-04) and that '[w]e, the Dutch, have never been asked [about the euro] (..). We are being told to respect others for their culture, but we have to abandon our own' (04-07-2000).

Summarising, whereas the second discourse we distinguished took the state's alleged dysfunctioning as a sign of its alienation from everyday reality, the discourse analysed in this category attributes it to the serving of vested interests. Instead of taking care of the general interest and performing public services for the people, the state, its agencies and officials are considered to be totally corrupt and accused of abusing their power. Such allegations show a striking resemblance with those expressed by contemporary populist parties with regard to the ‘established, corrupt elite’ (cf. Taggart, 2000; Canovan, 2005; Mudde, 2004; 2010).

\section{Conclusion}

Even though the political discontents of citizens in western societies have been widely studied and acknowledged, it has thus far remained unclear what these are exactly about. Studies based on surveys measure the level or degree of those discontents in abstract and general terms, such as the 'level of trust in government'. And studies that did analyse the content of political discontents have typically focused on institutionalised populist discourses. Consequently, hardly any insights on the nature and content of political discontents as these are voiced by citizens themselves exist, while these can be of great value for scholarly endeavours aimed at understanding why the state did fall from grace in western countries in recent decades (cf. Hay and Stoker, 2009; Kaina, 2008; Van Wessel 2010). That is why we set out to study what these

\footnotetext{
${ }^{12}$ This letter's obviously intentional grammatical error ('Us' as a subject) has been left untouched in the translation.
} 
political discontents in the Netherlands are about by means of an interpretative content analysis of the letters to the editor section of Dutch popular daily De Telegraaf in the 2000s (2000-2009), which has been selected strategically for the issue at hand.

The analysis of the letters that expressed discontents about the government, its agencies, officials, politicians and parties - shorthand: 'the state' - demonstrates that popular political discontents do not entail one unambiguous type of allegations. Instead, we inductively arrived at three discourses of political discontent: the incompetent state, the alienated state and the corrupted state. The first discourse has similarities with Norris' notion of the 'critical citizens', whose high aspirations and critical assertiveness are reflected in their attempts to correct the state at particular points (1999; 2011; cf. Tarrow, 2000). As such, the discourse of the incompetent state represents a form of critical citizenship that points out what is in need of improvement, often accompanied with suggestions on how to do so. The discourse on the alienated state, on the other hand, reveals a less constructive stance vis-à-vis the state, as it accuses it of being completely detached from the reality and everyday lives of ordinary citizens. Whereas the first discourse is still concerned with the improvement of the functioning of the state, the second merely observes the state as an incomprehensible bureaucratic system lost in its own rules and procedures. The latter discourse therefore reflects the Weberian notions that feelings of meaninglessness, alienation and dehumanisation occur when processes of rationalisation progress to a point where formal rationalism reigns over human values (cf. Berger et al., 1974 [1973]; Brubaker, 1982). The third discourse - the corrupted state - is a more cynical one, as it interprets the dysfunctioning of the state as purposeful action of those who use their position for their own and group interests, both materially and ideologically. In this type the state is not so 
much a-moral (as in the second) but primarily immoral. The identification of these three discourses of political discontents has relevance for at least two academic debates.

First of all, our findings have implications for the work of scholars who discuss the decline of political trust and its consequences. The three discourses that we discerned on the basis of our analysis particularly have implications for the question whether or not public trust in political institutions can be restored with policy interventions. This is a core issue in the academic debate. Halman (2006: 97), for instance, argues that declining levels of trust can be 'repaired' since trust in the government is largely dependent on policy evaluations and people's image of politics (cf. Akkerman, 2006). Stoker (2006: 10) aligns with this view: 'Many citizens', he argues, 'fail to fully appreciate that politics in the end involves the collective imposition of decisions' that ‘demands a complex communication process and generally produces messy compromise'. Elaborating on that line of thought, Hibbing and Theiss-Morse (1995: 161) propose 'to teach the (..) public that debate and compromise are not synonymous with bickering and selling out'. They hence plea for national debate and institutional reform to ease proliferating discontents and to restore trust in politics and politicians. This 'reform argument' is, however, countered by scholars like Russell Dalton who argue that such reforms will not increase trust in the government, as '[t]he 'new civic culture' of advanced industrial democracies' is characterised by 'a public skeptical of [governments'] motivations, doubtful about the institutions of representative democracy, and willing to challenge political elites' (2005: 150).

Our findings suggest that the question of whether policy interventions can solve the problem people have with the state cannot be answered in an 'either/or' fashion since these 'problems' vary substantially. Instead of making a priori claims about the nature of the problem, after all, 'the first step in solving any problem is to find out what the problem is - or, in the case 
of social and political problems, what the people believe the problem is' (Lipset and Schneider, 1983: 9). This study provided a first step herein and demonstrated that at least three politicaldiscontent discourses exist, which require, if considered necessary, differentiated approaches. Whereas the first of the discourses we discerned might be successfully repaired by means of policy initiatives, the others might not be, or even be aggravated. In addition, in this study we have grouped a relatively wide range of public actors under the label of 'the state'. Although this has served the explorative purpose of our research question, future research may specify whether the same critical discourses are levelled at all of those actors or whether particular actors are more vulnerable to specific discourses. The former case would imply a more generalized culture of discontent and the latter case might provide a basis for policy interventions. Such interventions, hence, would need to be customised and adapted to the specific types of discontents people have about the state. The formulation of such policies, we agree with Lipset and Schneider (idem), is however not the responsibility of scientists, but of politicians.

In addition, parts of the discontents described in this study resonate with what is commonly understood as (right-wing) populism (Mudde, 2004), and our findings therefore also have relevance for the debate on that matter. Although the first discourse discerned tends to 'correct' the state and can hardly be considered populism as defined by Mudde and outlined in the introduction, the other two types can. Whereas the second discourse of the alienated state discredits established parties and politicians for being out of touch with everyday reality, the third one accuses those parties and politicians of being corrupted. These two discourses represent two features of the populist ideology, which typically 'excludes elements it sees as alien, corrupt or debased' (Taggart, 2000: 3). Our study, therefore, indicates that these populist discourses can also be studied outside the political-institutional sphere (cf. Rooduijn, 2013). All in all, the 
relevance of our findings for the debates on trust in politics and contemporary populism demonstrates that the study of political discontents can greatly benefit from a focus beyond the clearly demarcated political-institutional realm as well as on those formulated by citizens themselves. Such a focus can lead to a better understanding of those discontents amongst ordinary citizens, particularly in times when there are no populist parties to express them.

Some limitations of the present study may, nonetheless, inform future research on contemporary political discontents. First of all, as we have argued in the former paragraph, the discontents our analysis has identified are predominantly right-leaning. While this is in line with the analysis of a 'silent counter-revolution' (Ignazi, 1992), recent developments in the Dutch political landscape, in which new-rightist parties have taken up government responsibilities, make the emergence of other (e.g., leftist) discontents plausible (Dekker et al., 2013: 95-102). To inform theoretical advancement pertaining to popular political discontents in general, new research questions may thus inquire whether the classification proposed here is exhaustive or perhaps in need of supplements or alterations when studying other groups. Likewise, the Dutch context, with its particular 'consensus democratic' tradition (Hendriks, 2009; cf. Lijphart, 1968) may limit the generalizability of our typology. Finally, it remains to be seen to what degree our results rely on the decision to study letters to the editor. These are, after all, subject to selection and editing by the newspaper (Wahl-Jorgenson, 2004), while online content is less heavily moderated and may thus offer more variation.

A more general question that comes to mind concerns the study's political relevance, or the consequences these different political discontents may have with respect to people's political behaviour. Do specific critical discourses spark specific political behaviour? People may, for example, motivate changes in their voting behaviour by arguing in one of these three ways. 
While the relatively innocent claims of incompetence may 'only' inspire electoral mobility, the most severe of the three allegations, that of corruption (Van der Meer, 2010: 520), seems more likely to inform a choice for a radical alternative like a populist party or abstention from voting altogether. How these different discontents relate to people's subsequent political action is therefore an important research question for the time to come. 


\section{References}

Akkerman, T. (2006) 'Politiek vertrouwen. Wat staat er op het spel? [Political trust. What's at stake?],' in Korsten, A. and P. de Goede, Bouwen aan vertrouwen in het openbaar bestuur. Diagnoses en remedies [Building trust in the public administration. Diagnoses and remedies]. 's-Gravenhage: Elsevier Overheid, 101-13.

Berger, P.L., B. Berger and H. Kellner (1974 [1973]) The Homeless Mind. Modernization and Consciousness. Harmondsworth: Penguin.

Bovens, M. and A. Wille (2008) 'Deciphering the Dutch drop: ten explanations for decreasing political trust in The Netherlands', International Review of Administrative Sciences, 74, 283305.

Bovens, M. and A. Wille (2011) 'Falling or fluctuating trust levels? The case of The Netherlands', in: Hooghe, M. and S. Zmerli (eds.) Political Trust: Why context matters, Colchester: ECPR Press, 47-66.

Brubaker, R. (1984) The Limits of Rationality: An Essay on the Social and Moral Thought of Max Weber. London: Allen \& Unwin.

Canovan, M. (1999) “Trust the People!’ Populism and the Two Faces of Democracy’, Political Studies, 47, 2-16.

Canovan, M. (2005) The People. Cambridge: Polity.

CBS Statline (2009) 'Media en ICT; gebruik televisie, krant, pc en internet, 1997-2008 [Media and ICT; use of television, PC and Internet]', accessed September 10, 2013 at http://statline.cbs.nl/StatWeb/publication/?VW=T\&DM=SLNL\&PA=70655ned\&D1=14$\underline{16,29-147 \& D 2=0 \& D 3=a \& H D=130910-1041 \& H D R=T \& S T B=G 1, G 2}$. 
Charmaz, K. (2006) Constructing Grounded Theory: A Practical Guide through Qualitative Analysis. London, Thousand Oaks, New Delhi: Sage Publications.

Dalton, R. J. (2005) 'The Social Transformation of Trust in Government’, International Review of Sociology, 15, 133-54.

Dekker, P., L. Halman and T. van der Meer (2006) 'Ontwikkelingen in politiek vertrouwen in Europa, 1981- 2004 [Trends in political trust in Europe, 1981-2004],' in Korsten, A and P. de Goede (eds.) Bouwen aan vertrouwen in het openbaar bestuur. Diagnoses en remedies.'s-Gravenhage: Elsevier Overheid, 61- 78.

Dekker, P. and J. den Ridder (2011) Stemming onbestemd. Tweede verdiepingsstudie Continu Onderzoek Burgerperspectieven [The undefined mood. Second in-depth study Citizens' Outlook Barometer]. Den Haag: Sociaal en Cultureel Planbureau.

Dekker, P., L. van Noije and J. den Ridder (2013) ‘Achtergrondstudie van het SCP: een overvloed aan onbehagen [Background study of the Social Cultural Planning bureau: an abundance of discontents]', in Raad voor Maatschappelijke Ontwikkeling, Het onbehagen voorbij. Een wenkend perspectief op onvrede en onmacht [Beyond discontents. An appealing perspective on dissatisfaction and powerlessness] . Den Haag: RMO, 60- 171.

Glaser, B.G., and A. Strauss (1967) The Discovery of Grounded Theory: Strategies for Qualitative Research. Chicago: Aldine de Gruyter.

Halman, L. (2006) 'De politiek vertrouwen? Waarom zou je? Een empirische analyse in 33 Europese landen [Trust politics? Why would you? An empirical analysis in 33 European countries],' in: Korsten, A. and P. de Goede, Bouwen aan vertrouwen in het openbaar bestuur. Diagnoses en remedies .'s-Gravenhage: Elsevier Overheid, 79- 99.

Hay, C. (2007) Why We Hate Politics. Cambridge: Polity. 
Hay, C. and G. Stoker (2009) 'Revitalising Politics: Have We Lost the Plot?,' Representation, 45, 225-36.

Hendriks, F. (2009) 'Contextualizing the Dutch drop in political trust: connecting underlying factors', International Review of Administrative Sciences, 75, 473-91.

Hibbing, J.R. and E. Theiss-Morse (1995) Congress as Public Enemy. Public Attitudes Toward American Political Institutions. Cambridge: Cambridge University Press.

Hijmans, E. (1996) 'Review Essay. The Logic of Qualitative Media Content Analysis: A Typology’, Communications, 21, 93-108.

Houtman, D. (2011) Counterculture 2.0, Key note lecture 11th Dag van de Sociologie, May 26th 2011, Gent.

Houtman, D., P. Achterberg and R. Kemmers (2012) ‘De wedergeboorte van de fact-free politics. Pim Fortuyn en de nieuwe tegencultuur (2002-2012) [The rebirth of the fact-free politics. Pim Fortuyn and the new counterculture]', Beleid en Maatschappij, 39, 179-93. Ignazi, P. (1992) 'The Silent Counter-Revolution. Hypotheses on the Emergence of Extreme Right-Wing Parties in Europe’, European Journal of Political Research, 22, 3-34.

Inglehart, R. (1977) The Silent Revolution: Changing Values and Political Styles among Western Public. Princeton: Princeton University Press.

Janssen, S., G. Kuipers and M. Verboord (2008) ‘Cultural Globalization and Arts Journalism: The International Orientation of Arts and Culture Coverage in Dutch, French, German, and U.S. Newspapers, 1955 to 2005’ American Sociological Review, 78, 719-40.

Kaina, V. (2008) 'Declining Trust in Elites and Why We Should Worry About It - With Empirical Evidence From Germany’, Government and Opposition, 43, 405-23. 
Korsten, A. and P. de Goede (eds.)(2006) Bouwen aan vertrouwen in het openbaar bestuur. Diagnoses en remedies [Building trust in the public administration. Diagnoses and remedies]. 's-Gravenhage: Elsevier Overheid.

Lijphart, A. (1968) The politics of accommodation: pluralism and democracy in the Netherlands. Berkeley: University of California Press.

Lipset, S. M. and W. Schneider (1983) The Confidence Gap: Business, Labor and Government in the Public Mind. New York: Free Press.

Mény, Y. and Y. Surel (eds.)(2002) Democracies and the Populist Challenge. Basingstoke: Palgrave.

Mudde, C. (2004) ‘The Populist Zeitgeist’, Government and Opposition, 39, 542-63.

Mudde, C. (2010) ‘The populist Radical right: A Pathological Normalcy’, West European Politics, 33, 1167-86.

Norris, P. (ed.) (1999) Critical Citizens: Global Support for Democratic Government. Oxford: Oxford University Press.

Norris, P. (2011) Democratic Deficit. Critical Citizens Revisited. New York: Cambridge University Press.

Pauwels, T. (2011) 'Measuring populism: A quantitative text analysis of party literature in Belgium', Journal of Elections, Public Opinion and Parties, 21, 97-119.

Pharr, S. J. and R. D. Putnam (eds.)(2000) Disaffected Democracies. What's Troubling the Trilateral Countries? Princeton: Princeton University Press.

Riffe, D., C. F. Aust, and S. R. Lacy (1993) ‘The Effectiveness of Random, Consecutive Day and Constructed Week Samples in Newspaper Content Analysis,' Journalism Quarterly, 70, 133-39. 
Rooduijn, M. (2013) A Populist Zeitgeist? The Impact of Populism on Parties, Media and the Public in Western Europe. Doctoral dissertation, University of Amsterdam.

Roszak, T. (1969). The Making of a Counter Culture: Reflections on the Technocratic Society and its Youthful Opposition. New York: Doubleday.

Stoker, G. (2006) Why Politics Matters. Making Democracy Work. Basingstoke: Palgrave Macmillan.

Taggart, P. (2000) Populism. Buckingham: Open University Press.

Tarrow, S. (2000) 'Mad Cows and Social Activists: Contentious Politics in the Trilateral Democracies', in S.J. Pharr and R. D. Putnam (eds.) Disaffected Democracies. What's Troubling the Trilateral Countries? Princeton: Princeton University Press, 270-90.

Uitermark, J., M. Oudenampsen, B. van Heerikhuizen and R. van Reekum (eds.) (2012) 'Power to the People!' Een anatomie van het populisme. Den Haag: Boom Lemma.

Van der Meer, T. (2010). 'In what we trust? A multi-level study into political trust as an evaluation of state characteristics', International Review of Administrative Sciences, 76, 517-536.

Van de Walle, S., S. van Roosbroek and G. Boeckaert (2008) 'Trust in the public sector: is there any evidence for a long-term decline?', International Review of Administrative Sciences, 74, 47-64.

Van Wessel, M. (2010) 'Political Disaffection. What We Can Learn from Asking the People’, Parliamentary Affairs, 63, 504-23.

Wahl-Jorgenson, K. (2004) ‘A “Legitimate Beef” or “Raw Meat”? Civility, Multiculturalism, and Letters to the Editor', The Communications Review, 7, 89-105. 
Wolf, M. (2009) Het geheim van De Telegraaf. Geschiedenis van een krant [The secret of De Telegraaf. A newspaper's history]. Amsterdam: Boom. 